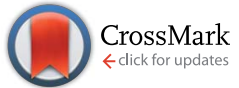

Cite this: Chem. Sci., 2017, 8, 3720

Received 20th January 2017

Accepted 7th March 2017

DOI: $10.1039 / \mathrm{c} 7 \mathrm{sc} 00300 \mathrm{e}$

rsc.li/chemical-science

\section{(Phosphanyl)phosphaketenes as building blocks for novel phosphorus heterocycles $\dagger$}

\begin{abstract}
Max M. Hansmann, David A. Ruiz, Liu Leo Liu, Rodolphe Jazzar and Guy Bertrand*
Although $\mathrm{BH}_{3}$ simply coordinates the endocyclic $\mathrm{P}$ of (phospholidino)phosphaketene $1^{\text {Dipp }}$, the bulkier $\mathrm{B}\left(\mathrm{C}_{6} \mathrm{~F}_{5}\right)_{3}$ gives rise to a zwitterionic diphosphirenium, which is a novel type of $2 \pi$-electron aromatic system as shown by the calculated NICS values. While the reaction of $1^{\text {Dipp }}$ with $\mathrm{Na}\left[\mathrm{PCO}(\text { dioxane) })_{x}\right.$ is unselective, the same reaction with the sterically bulky (phospholidino)phosphaketene $1^{\mathrm{Ar**}}[\mathrm{Ar} * *=2,6$-bis[di(4-tert-butylphenyl) methyl]-4-methylphenyl selectively affords a sodium bridged dimer containing a hitherto unknown $\lambda^{3}, \lambda^{5}, \lambda^{3}$ triphosphete core. The latter formally results from " $\mathrm{P}^{-\prime}$ addition to a 1,3-P/C-dipole. Similarly, adamantyl isonitrile adds to $1^{\text {Dipp }}$ giving a 4-membered phosphacycle. In contrast to 1 , the phosphaketene derived from the electrophilic diazaphospholidine-4,5-dione is unstable and reacts with a second molecule of $\mathrm{Na}$ [PCO(dioxane) $)_{x}$ to afford a 1,3,4-oxadiphospholonide derivative.
\end{abstract}

\section{Introduction}

Compared to the well-known isocyanates $[\mathrm{R}-\mathrm{N}=\mathrm{C}=\mathrm{O}]$, the chemistry of their heavier homologues, namely phosphaketenes $[\mathrm{R}-\mathrm{P}=\mathrm{C}=\mathrm{O}]$, has been largely unexplored. This is presumably the result of limited synthetic access and poor stability of their alkyl and aryl substituted derivatives. ${ }^{1}$ Indeed, pioneering work by Appel et al. showed that although the very bulky $\left[\mathrm{C}_{6} \mathrm{H}_{3}\left({ }^{t} \mathrm{Bu}\right)_{3}\right]-$ $\mathrm{P}=\mathrm{C}=\mathrm{O}$ can be isolated at room temperature, ${ }^{t} \mathrm{Bu}-\mathrm{PCO}$ dimerizes above $-60{ }^{\circ} \mathrm{C}^{2}$ However, the recent discovery of efficient preparation ${ }^{3}$ of phosphaethynolate salts $\left(\mathrm{PCO}^{-} \mathrm{M}^{+}\right)^{4}$ has allowed access to group $14-\left(\mathrm{Si},{ }^{5} \mathrm{Sn},{ }^{6} \mathrm{Ge},{ }^{7} \mathrm{~Pb}^{5}\right)$ and transition metal- $(\mathrm{Re}, \mathrm{Au}, \mathrm{Co}, \mathrm{W})^{8}$ substituted phosphaketenes. In addition, the reaction of chlorodiaza-phospholidines and -phospholines ${ }^{9}$ with $\mathrm{Na}\left[\mathrm{PCO}(\text { dioxane })_{x}\right]$ has allowed for the isolation of (phosphino)phosphaketenes $\mathbf{1}^{\mathbf{1 0}}$ and $\mathbf{1}^{\prime},{ }^{\mathbf{1 1}}$ respectively (Scheme 1). Although the phosphaketene moiety of $\mathbf{1}^{\prime}$ reacts with the unsaturated backbone to give various rearrangement products, ${ }^{11}$ (phospholidino)-phosphaketene $\mathbf{1}^{\text {Dipp }}$ is thermally very stable (heating a toluene solution of $\mathbf{1}^{\text {Dipp }}$ overnight at $80{ }^{\circ} \mathrm{C}$ does not lead to decomposition or any rearrangement products), which allows for studying the reactivity of the $[\mathrm{P}]-$ PCO moiety. We have already reported that elimination of $\mathrm{CO}$ occurred under irradiation of $\mathbf{1}^{\mathbf{A r}^{* * *}}$, affording the corresponding room temperature stable phosphinidene $2^{\mathbf{A r * *}},{ }^{10 a}$ while addition

UCSD-CNRS Joint Research Chemistry Laboratory (UMI 3555), Department of Chemistry, University of California San Diego, La Jolla, CA 92093-0343, USA. E-mail: guybertrand@ucsd.edu

$\dagger$ Electronic supplementary information (ESI) available: Characterization data, crystallographic data and Cartesian coordinates of DFT optimized structures. CCDC 1432815(4), 1432814 (5), 1528506 (6), 1432817 (8), 1528508 (10) and $1528507\left(\mathbf{1 0}^{\prime}\right)$. For ESI and crystallographic data in CIF or other electronic format see DOI: $10.1039 / \mathrm{c} 7 \mathrm{sc} 00300 \mathrm{e}$

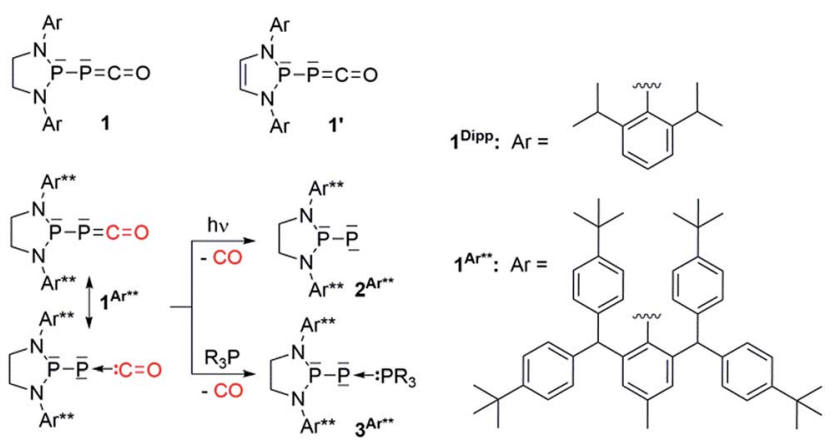

Scheme 1 Recently reported (phosphino)phosphaketenes 1 (ref. 10) and $1^{\prime},{ }^{11}$ elimination and substitution of $\mathrm{CO}$ leading to the stable phosphinidene $2^{\mathrm{Ar**}}$ and adducts $3^{\mathrm{Ar**}}$, respectively.

of phosphines to $\mathbf{1}^{\mathrm{Ar}{ }^{* *}}$ and $\mathbf{1}^{\text {Dipp }}$ leads to adducts $3 .{ }^{12}$ In both of these reactions, the phosphaketene group acts as a phosphinidene-carbonyl adduct. This behavior is reminiscent of the chemistry of transition metal carbonyl complexes, and it is noteworthy that before our work the chemistry of main group carbonyl compounds ${ }^{13}$ was essentially limited to boranes, ${ }^{14}$ polyboranes ${ }^{15}$ and carbenes. ${ }^{16}$ Herein we report that the P-PCO scaffold can also react without loss of $\mathrm{CO}$ to give access to a variety of hitherto unknown phosphorus heterocycles.

\section{Results and discussion}

We started our investigation by studying the electrophilic activation of the [P]-PCO moiety of $1^{\text {Dipp }}$, with the aim of triggering the loss of carbon monoxide. We chose two different boronderived Lewis acids. Upon addition of excess $\mathrm{BH}_{3}$, simple coordination to the endocyclic $\mathrm{P}$ center occurs giving $\mathbf{4}$, as 


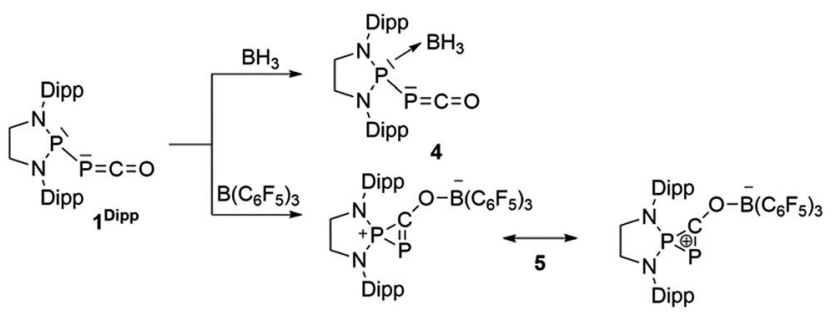

Scheme 2 Reactivity of $1^{\text {Dipp }}$ with boranes.

shown by the ${ }^{31} \mathrm{P}$ NMR spectrum [ $-226 \mathrm{ppm}(\mathrm{d}),+131 \mathrm{ppm}$ (br. d), $\left.J_{\mathrm{PP}}=295 \mathrm{~Hz}\right]$ and by a single crystal X-ray diffraction study (Scheme 2; Fig. 1, top). To understand the regioselectivity of the reaction, three $\mathrm{BH}_{3}$ adduct isomers were optimized at the B3LYP-D3BJ/def2-TZVP level of theory (Fig. 2). The results show that the observed product $\mathbf{4}$ is more thermodynamically stable than $\mathbf{4 b}$ and $\mathbf{4 c}$ by +13.2 and $+24.7 \mathrm{kcal} \mathrm{mol}^{-1}$ (gas-phase electronic energies), respectively. Moreover, since the absolute coefficient of the HOMO of $\mathbf{1}^{\text {Dipp }}$ at the endocyclic $\mathrm{P}(0.42)$ is much larger than those at the phosphorus of PCO (0.32) and at $\mathrm{O}(0.11), 4$ is also the kinetic product of the reaction.

Due to the steric environment around the endocyclic P atom, we wondered whether a larger borane would react at a different

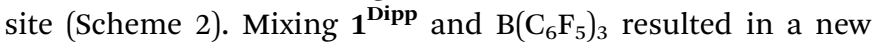
product as observed by ${ }^{31} \mathrm{P}$ NMR spectroscopy with two sharp doublets at $\delta=+206$ and $-11 \mathrm{ppm}\left(J_{\mathrm{PP}}=215 \mathrm{~Hz}\right)$. An X-ray diffraction study revealed the formation of the unusual zwitterionic diphosphirenium 5 (Fig. 1, bottom). ${ }^{17}$ The PP bond distance $(2.0804(14) \AA)$ becomes significantly shorter than in

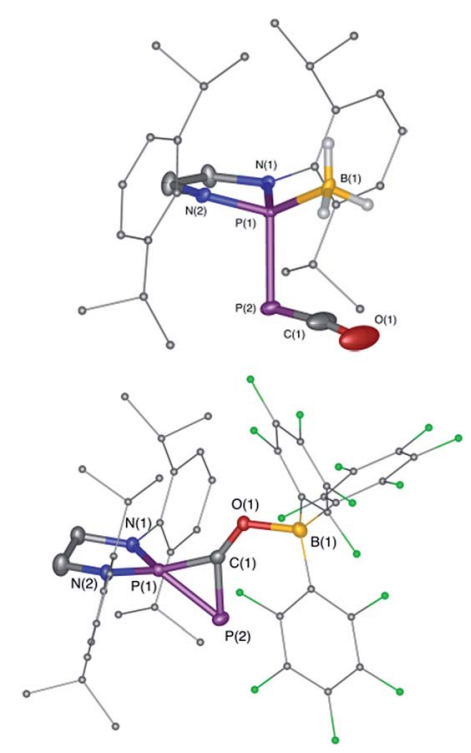

Fig. 1 Solid-state structures of 4 (top) and 5 (bottom). Hydrogen atoms are omitted for clarity. Ellipsoids shown at 50\% probability. Selected bond parameters for 4 in [Å] and [ $\left.{ }^{\circ}\right]$ : P1-P2 2.2657(16), P2-C1 1.533(6), C1-O1 1.165(8), P1-B1 1.906(6), P1-P2-C1 96.8(2), P2-C1O1 171.9(6), B1-P1-P2 113.0(2); and 5: P1-P2 2.0804(14), P2-C1 1.748(4), P1-C1 1.727(4), C1-O1 1.289(4), O1-B1 1.560(5), P2-P1-C1 53.67(13), P1-C1-P2 73.55(15), P1-C1-O1 143.7(3), C1-O1-B1 125.0(3).
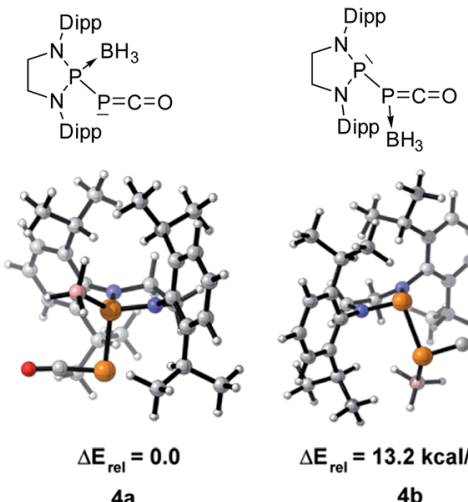<smiles>COC#[PH]C1PN2CCN(O)P12</smiles>

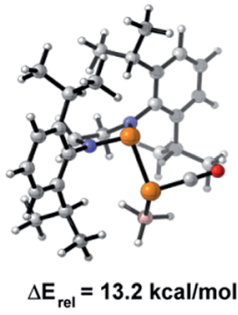

4b

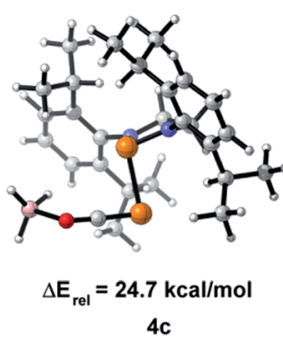

4c
Fig. 2 Optimized structures of three $\mathrm{BH}_{3}$ adduct isomers and their relative electronic energies at the B3LYP/def2-TZVP level of theory.

$1^{\text {Dipp }}(2.3782(8) \AA)^{10}$ and is in the outer range for PP double bonds (1.985-2.050 ̊̊). ${ }^{18}$ Concomitantly, the CO bond elongates from 1.170(3) $\AA$ in $\mathbf{1}^{\text {Dipp }}$ to 1.289(4) $\AA$ in 5. It is important to note that the computed nucleus independent chemical shift (NICS) ${ }^{19}$ values for the central three-membered ring are negative $[\operatorname{NICS}(0)=-17.33$ and $\operatorname{NICS}(1)=-11.71 \mathrm{ppm}]$, which suggests that the three-membered ring of 5 is a $2 \pi$-electron aromatic system. Mechanistically, the interaction of the borane with the oxygen atom induced a ring closure between the carbon ketene atom and the endocyclic P center. Alternatively, a reviewer suggested that the borane abstracts the $\mathrm{PCO}^{-}$moiety to form a close ion contact-pair $[\mathrm{P}]^{+}\left[\mathrm{PCO}-\mathrm{BR}_{3}\right]^{-}$followed by coordination of the phosphaalkyne to the electrophilic phosphorus center. ${ }^{20}$ However, DFT calculations indicate that the heterolytic cleavage of the P-P bond is energetically very costly. Moreover, a transition state in agreement with a concerted Lewis acid activation of 1 has been located using the small $\mathrm{BF}_{3}$ Lewis acid as a model (Fig. S1 $\dagger$ ). Interestingly, $\mathbf{5}$ can be regarded as $\mathbf{1}^{*}$, the cyclic isomer of $\mathbf{1}$ trapped by a Lewis acid. DFT calculations predict an energy barrier of $22.4 \mathrm{kcal} \mathrm{mol}^{-1}$ for the endergonic interconversion of 1 into its cyclic isomer $1^{*}(\Delta E=22.1 \mathrm{kcal}$ $\mathrm{mol}^{-1}$ ) (Scheme 3). Note that the [P]-OCP $\left(\mathbf{1}^{* *}\right)$ and $[\mathrm{P}=\mathrm{O}]-\mathrm{CP}$ $\left(1^{* * *}\right)$ isomers are predicted to be 15.2 and $11.5 \mathrm{kcal} \mathrm{mol}^{-1}$, respectively, higher in energy than $\mathbf{1 .}^{21}$

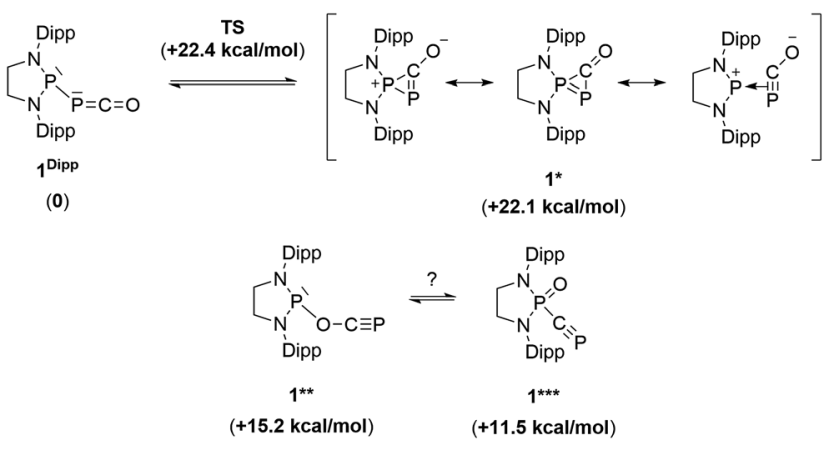

Scheme 3 Possible isomers of the P-PCO moiety and their relative electronic energies (in brackets) compared to $1^{\text {Dipp }}$ (B3LYP-D3BJ/CCpVDZ level of theory). 


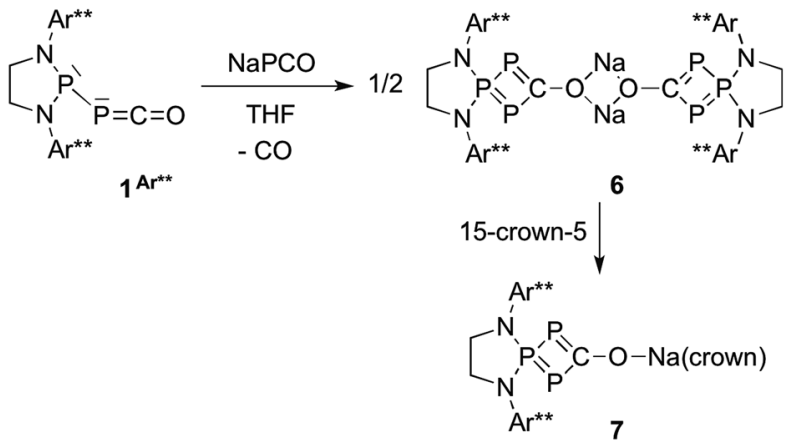

Scheme 4 Synthesis of the 1,2,3-triphosphete 7 via a formal [1 + 3]cycloaddition of $\mathrm{P}^{-}$to the PPC unit of $1^{\text {Ar*** }}$.

While the reaction of $\mathbf{1}^{\text {Dipp }}$ with $\mathrm{Na}\left[\mathrm{PCO}(\text { dioxane })_{x}\right]$ is unselective, giving rise to several compounds, we observed that the same reaction with the sterically bulky (phosphino)phosphaketene $\mathbf{1}^{\mathbf{A r}}{ }^{* *}$, featuring 2,6-bis[di(4-tert-butylphenyl)methyl]-4methylphenyl substituents, ${ }^{22}$ was highly selective. Independent of the excess $\mathrm{Na}\left[\mathrm{PCO}(\text { dioxane) })_{x}\right]$ used (or one equivalent), the ${ }^{31} \mathrm{P}$ NMR spectrum showed the formation of a single product $\left[+126.1(\mathrm{~d}),+69.6 \mathrm{ppm}(\mathrm{t}), J_{\mathrm{PP}}=302 \mathrm{~Hz}\right]$. An X-ray diffraction study revealed that it was the sodium bridged dimer 6 containing the hitherto unknown $\lambda^{3}, \lambda^{5}, \lambda^{3}$-triphosphete core (Scheme 4, Fig. 3). Upon addition of 15-crown-5 to 6 a slight shift of the ${ }^{31} \mathrm{P}$ NMR signals $\left[+119.7\right.$ (d) and $+78.8 \mathrm{ppm}(\mathrm{t}), J_{\mathrm{PP}}=$ $310 \mathrm{~Hz}$ ] was observed and the corresponding monomer 7 could be characterized by X-ray diffraction (Fig. 4).

The formation of the triphosphete scaffold formally results from a $[1+3]$-cycloaddition of " $\mathrm{P}^{-{ }^{23}}$ (from NaPCO) to the PPC unit. Indeed, when the ${ }^{13} \mathrm{C}$ labeled phosphaketene $\mathbf{1}^{\mathbf{A r}^{* *}}$ was reacted with non- ${ }^{13} \mathrm{C}$-labeled $\mathrm{Na}\left[\mathrm{PCO}(\text { dioxane })_{x}\right]$, we observed an intense broad resonance ${ }^{24}$ at $\delta^{13} \mathrm{C}=250.2$ ppm demonstrating that the PPCO moiety remains, at least to a large extent, in the final product. Mechanistically, DFT calculations indicate

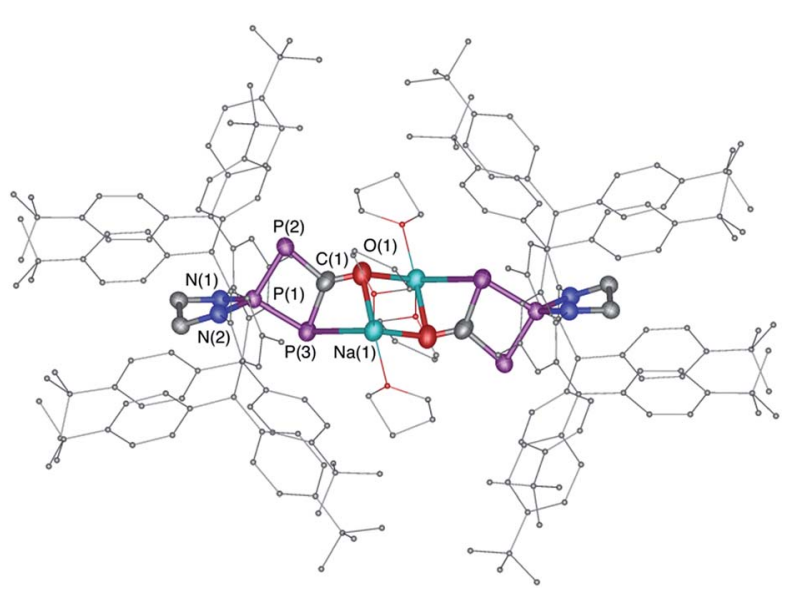

Fig. 3 Solid-state structure of 6 . Hydrogen atoms are omitted for clarity. Ellipsoids shown at 50\% probability. Selected bond parameters in [Å] and [ $\left.{ }^{\circ}\right]$ : P1-P2 2.1213(15), P1-P3 2.1371(14), P2-C1 1.820(5), C1P3 1.854(5), C1-O1 1.257(5), O1-Na1 2.305(4), P3-P1-P2 91.44(5), P1P2-C1 78.76(15).

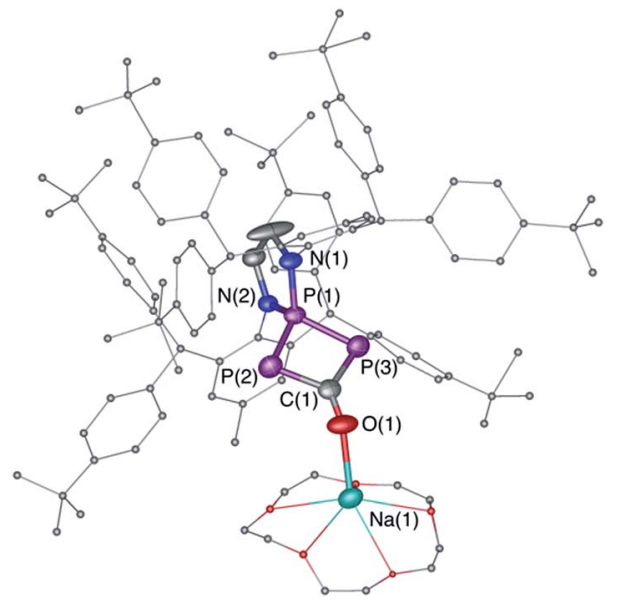

Fig. 4 Solid-state structure of 7. Hydrogen atoms are omitted for clarity. Structural data are not presented due to the low quality of the $\mathrm{X}$-ray data.

that the reaction involves an initial attack onto the carbon atom of the PCO moiety followed by cyclization with simultaneous loss of $\mathrm{CO}\left(\Delta G^{\star}=16.1 \mathrm{kcal} \mathrm{mol}^{-1}\right)$ (see Fig. S2 in ESI $\dagger$ ). Aside from the formation of a novel type of phosphorus heterocycle, these results are interesting because they give important information on the synthesis of (phosphino)phosphaketenes $\mathbf{1}$. Indeed, to prepare the latter, it is crucial to use only one equivalent of $\mathrm{Na}\left[\mathrm{PCO}(\text { dioxane })_{x}\right]$ and toluene as the solvent in which $\mathrm{Na}\left[\mathrm{PCO}(\text { dioxane })_{x}\right]$ is only poorly soluble. Otherwise, instead of $\mathbf{1}$, heterocycles of type $\mathbf{6}$ are formed as the major product.

Serendipitously, we also prepared another novel type of phosphorus heterocycle formally resulting from a $[1+3]$ cycloaddition. As isonitriles and carbon monoxide are isoelectronic, we were interested in the thermal substitution of the CO in phosphaketene $\mathbf{1}^{\text {Dipp }}$ by an isonitrile, using our recently reported ligand exchange strategy. ${ }^{\mathbf{1 2}}$ Surprisingly, the isonitrile does not add at the phosphorus center of PCO to displace CO, as previously observed with phosphines, but attacks at the carbon. ${ }^{25}$ This is followed by a cyclization involving the endocyclic $\mathrm{P}$ and the resulting heterocycle 8 was isolated in $85 \%$ yield $\left(\delta^{31} \mathrm{P} 148.0\right.$ and $88.3 \mathrm{ppm}, J=370 \mathrm{~Hz}$ ) (Scheme 5, Fig. 5).

The formal insertion of an isonitrile giving 8 can be rationalized by a mechanism similar to that postulated for the insertion of P- leading to 6. According to DFT calculations, this process is exergonic by $6.1 \mathrm{kcal} \mathrm{mol}^{-1}$ with an energy barrier of $23.3 \mathrm{kcal} \mathrm{mol}^{-1}$ (Fig. 6, right). Note that direct

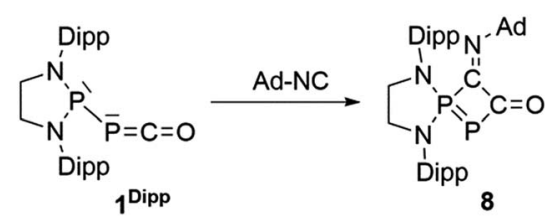

Scheme 5 Synthesis of heterocycle 8 via a formal [1 + 3]-cycloaddition of adamantyl isonitrile to the PPC unit of $1^{\mathrm{Ar}^{* *}}$. 


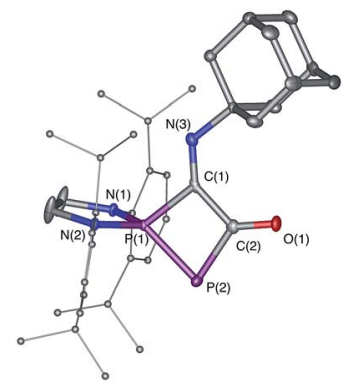

Fig. 5 Solid-state structure of 8 . Hydrogen atoms are omitted for clarity. Ellipsoids shown at $50 \%$ probability. Selected bond lengths $[\AA \AA]$ and angles [ ${ }^{\circ}$ ]: P1-P2 2.1028(11), P1-C1 1.837(3), C1-C2 1.535(4), C2P2 1.832(3), C2-O1 1.225(4), C1-N3 1.265(4), C2-P2-P1 77.96(11), $\mathrm{P} 2-\mathrm{P} 1-\mathrm{C} 1$ 84.17(10).

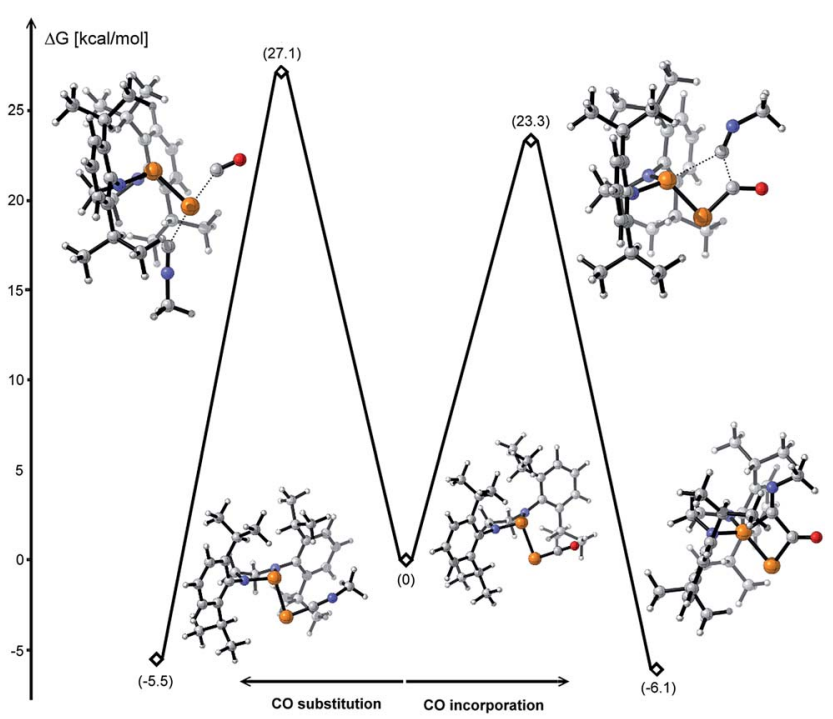

Fig. 6 Energy profiles for the CO substitution and incorporation of an isonitrile to 1 calculated at the B3LYP-D3BJ/cc-pVDZ level of theory.

substitution of CO by the isonitrile is also exergonic by $5.5 \mathrm{kcal} \mathrm{mol}^{-1}$ but with a higher activation energy barrier (27.1 kcal mol ${ }^{-1}$ ) (Fig. 6, left).

The difficulty in synthesizing (phosphino)phosphaketenes is illustrated by our attempt to prepare $\mathbf{1 1}$ derived from the electrophilic diazaphospholidine-4,5-dione (Scheme 6). A single

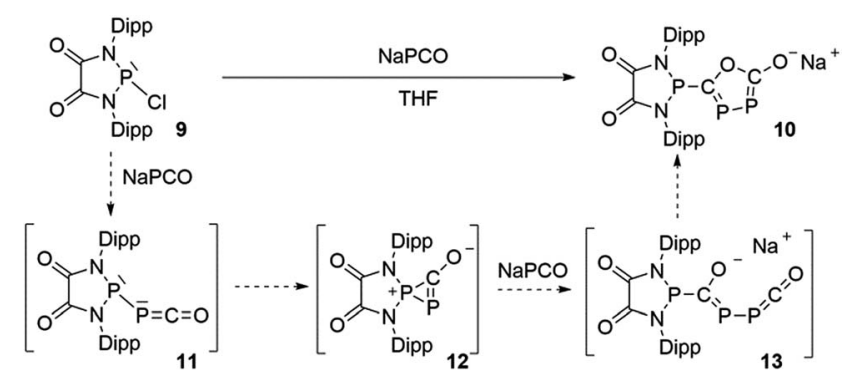

Scheme 6 Attempted synthesis of (phopshino)phosphaketene 11 and the formation of heterocycle 10 .

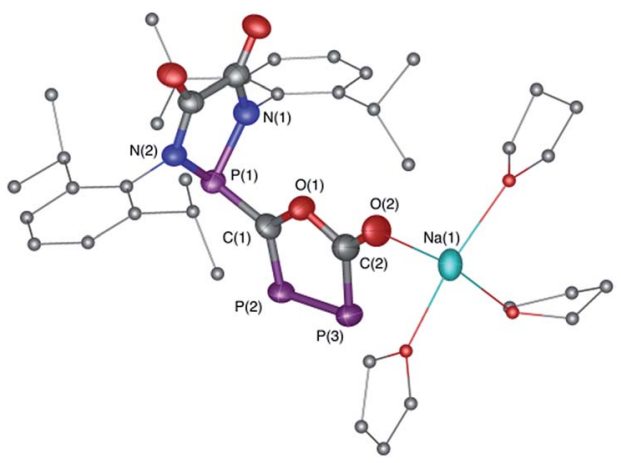

Fig. 7 Solid-state structure of 10 crystalized from THF. Hydrogen atoms and THF molecules coordinated are omitted for clarity. Ellipsoids shown at $50 \%$ probability. Selected bond parameters for 10 in [Å] and $\left[^{\circ}\right]$ : P1-C1 1.759(5), C1-P2 1.696(5), P2-P3 2.096(3), P3-C2 1.795(6), C2-O1 1.405(6), C2-O2 1.231(7), O1-C1 1.389(6), O2-Na1 2.329(4), P1-C1-P2 118.3(3), C1-P2-P3 94.9(2), P2-P3-C2 93.5(2).

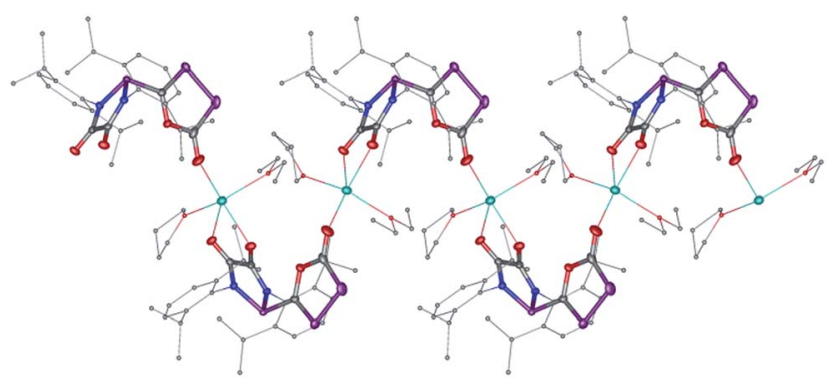

Fig. 8 Stolid-state structure of 10 crystalized from THF/Et ${ }_{2} \mathrm{O} / \mathrm{CH}_{3} \mathrm{CN}$ showing the polymeric chain nature. Ellipsoids shown at $50 \%$ probability.

product was formed upon mixing 9 with $\mathrm{NaPCO}$, but the ${ }^{31} \mathrm{P}$ NMR spectrum revealed the presence of three different phosphorus nuclei $\left[{ }^{31} \mathrm{P}\right.$ NMR $\delta=+323(\mathrm{dd}, J=466 \mathrm{~Hz}, 282 \mathrm{~Hz}) ;+48$ (d, $J=282 \mathrm{~Hz}) ;+45$ (d, $J=466 \mathrm{~Hz}) \mathrm{ppm}]$. An X-ray diffraction study revealed the 1,3,4-oxadiphospholonide core 10 (Fig. 7), a type of heterocycle previously only observed by Grützmacher et al. in the reaction of NaPCO with tetraphenyl-cyclopentadienone. ${ }^{26}$ Interestingly, in the solid-state this compound features a linear polymeric network structure in which the sodium cation is bridging between the diketone moiety and the phosphorus heterocycle (Fig. 8).

Mechanistically, it seems reasonable to postulate the initially formed (phosphino)phosphaketene $\mathbf{1 1}$ spontaneously rearranges into the spirocyclic zwitterionic derivative $\mathbf{1 2}$ which resembles the borane adduct $\mathbf{5}$. Then, a second equivalent of NaPCO induces a ring opening giving 13 , which undergoes a ring closure leading to the observed product $\mathbf{1 0 .}$

\section{Conclusions}

This work has shown that (phosphino)phosphaketenes are powerful building blocks in heterocyclic chemistry. In contrast to our recent reported $\mathrm{CO}$ substitution approach, ${ }^{12}$ this work 
demonstrates the feasibility of nucleophiles to add to carbon on the phosphaketene moiety. The endocyclic $\mathrm{P}$ center can either activate the phosphaketene by forming highly reactive diphosphirenium species or engage in ring closing reactions. Importantly the stability and chemical behaviour of these novel heterocycles is strongly dependent on the nature of the phosphino substituents.

\section{Acknowledgements}

Thanks are due to the NSF (CHE-1359809) for financial support. MMH is thankful to the Alexander von Humboldt foundation for a Feodor-Lynen scholarship and LL to the China Scholarship Council for a graduate fellowship. We are grateful to the Keck Foundation for funding the KeckII computer center. Dr Milan Gembicky and Dr Curtis Moore are greatly acknowledged for their help with X-ray diffraction.

\section{Notes and references}

1 For reviews on phosphaketenes, see: (a) J. Escudié, H. Ranaivonjatovo and L. Rigon, Chem. Rev., 2000, 100, 3639-3696; (b) R. Appel and F. Knoll, Adv. Inorg. Chem., 1989, 33, 259-361.

2 (a) R. Appel, In Multiple Bonds and Low Coordination in Phosphorus Chemistry, ed. M. Regitz and O. J. Scherer, Thieme, Stuttgart, Germany, 1990, pp. 188-190; (b) R. Appel, B. Laubach and M. Siraay, Tetrahedron Lett., 1984, 25, 4447-4448; (c) R. Appel and W. Paulen, Tetrahedron Lett., 1983, 24, 2639-2642; (d) R. Appel and W. Paulen, Angew. Chem., 1983, 95, 807-808; (e) V. Plack, J. R. Görlich, A. Fischer and R. Schmutzler, Z. Anorg. Allg. Chem., 1999, 625, 1979-1984; (f) A. H. Cowley, B. Pellerin, J. L. Atwood and S. G. Bott, J. Am. Chem. Soc., 1990, 112, 6734-6735; $(g)$ M.-A. David, D. S. Glueck, G. P. A. Yap and A. L. Rheingold, Organometallics, 1995, 14, 4040-4042; (h) M.-A. David, D. K. Wicht and D. S. Glueck, Organometallics, 1997, 16, 4768-4770; (i) R. Appel, P. Fölling, B. Josten, M. Siray, V. Winkhaus and F. Knoch, Angew. Chem., 1984, 96, 620621; (j) R. Appel, C. Porz and F. Knoch, Chem. Ber., 1986, 119, 2748-2755.

3 (a) Z.-J. Quan and X.-C. Wang, Org. Chem. Front., 2014, 1, 1128-1131; (b) F. F. Puschmann, D. Stein, D. Heift, C. Hendriksen, Z. A. Gal, H.-F. Grützmacher and H. Grützmacher, Angew. Chem., Int. Ed., 2011, 50, 84208423; (c) A. R. Jupp and J. M. Goicoechea, Angew. Chem., Int. Ed., 2013, 52, 10064-10067; (d) D. Heift, Z. Benkö, H. Grützmacher, A. R. Jupp and J. M. Goicoechea, Chem. Sci., 2015, 6, 4017-4024; (e) D. Heift, Z. Benkö and H. Grützmacher, Dalton Trans., 2014, 43, 831-840.

4 For the first preparation of the phosphaethynolate sodium salt: G. Becker, W. Schwarz, N. Seidler and M. Westerhausen, Z. Anorg. Allg. Chem., 1992, 612, 72-82.

5 D. Heift, Z. Benkő and H. Grützmacher, Dalton Trans., 2014, 43, 5920-5928.

6 D. Heift, Z. Benkö and H. Grützmacher, Chem.-Eur. J., 2014, 20, 11326-11330.
7 (a) S. Yao, Y. Xiong, T. Szilvasi, H. Grützmacher and M. Driess, Angew. Chem., Int. Ed., 2016, 55, 4781-4785; (b) Y. Wu, L. Liu, J. Su, J. Zhu, Z. Ji and Y. Zhao, Organometallics, 2016, 35, 1593-1596; (c) N. D. Rio, A. Baceiredo, N. Saffon-Merceron, D. Hashizume, D. Lutters, T. Müller and T. Kato, Angew. Chem., Int. Ed., 2016, 55, 4753-4758.

8 For transition-metal PCO complexes, see: (a) L. Liu, D. A. Ruiz, F. Dahchech, G. Bertrand, R. Suter, A. M. Tondreau and H. Grützmacher, Chem. Sci., 2016, 7, 2335-2341; (b) S. Alidori, D. Heift, G. Santiso-Quinones, Z. Benkő, H. Grützmacher, M. Caporali, L. Gonsalvi, A. Rossin and M. Peruzzini, Chem.-Eur. J., 2012, 18, 1480514811; (c) A. R. Jupp, M. B. Geeson, J. E. McGrady and J. M. Goicoechea, Eur. J. Inorg. Chem., 2016, 2016, 639-648; (d) C. Camp, N. Settineri, J. Lefèvre, A. R. Jupp, J. M. Goicoechea, L. Maron and J. Arnold, Chem. Sci., 2015, 6, 6379-6384.

9 D. Gudat, Dalton Trans., 2016, 45, 5896-5907.

10 (a) L. Liu, D. A. Ruiz, D. Munz and G. Bertrand, Chem, 2016, 1, 147-153; (b) M. M. Hansmann, R. Jazzar and G. Bertrand, J. Am. Chem. Soc., 2016, 138, 8356-8359.

11 Z. Li, X. Chen, M. Bergeler, M. Reiher, C.-Y. Su and H. Grützmacher, Dalton Trans., 2015, 44, 6431-6438.

12 M. M. Hansmann and G. Bertrand, J. Am. Chem. Soc., 2016, 138, 15885-15888.

13 For a comparison of transition metal reactivity with main group compounds see: (a) P. P. Power, Nature, 2010, 463, 171-177; (b) D. Martin, M. Soleihavoup and G. Bertrand, Chem. Sci., 2011, 2, 389-399.

14 (a) M. Finze, E. Bernhardt, A. Terheiden, M. Berkei, H. Willner, D. Christen, H. Oberhammer and F. Aubke, J. Am. Chem. Soc., 2002, 124, 15385-15398; (b) H. Braunschweig, R. D. Dewhurst, F. Hupp, M. Nutz, K. Radacki, C. W. Tate, A. Vargas and Q. Ye, Nature, 2015, 522, 327-330.

15 J. D. Glore, J. W. Rathke and R. Schaeffer, Inorg. Chem., 1973, 12, 2175-2178.

16 (a) V. Lavallo, Y. Canac, B. Donnadieu, W. W. Schoeller and G. Bertrand, Angew. Chem., Int. Ed., 2006, 45, 3488-3491; (b) C. Goedecke, M. Leibold, U. Siemeling and G. Frenking, $J$. Am. Chem. Soc., 2011, 133, 3557-3569; (c) T. W. Hudnall and C. W. Bielawski, J. Am. Chem. Soc., 2009, 131, 1603916041.

17 (a) F. Castan, A. Baceiredo, J. Fischer, A. De Cian, G. Commenges and G. Bertrand, J. Am. Chem. Soc., 1991, 113, 8160-8161; for a review on 3-membered phosphorus cycles, see: (b) F. Mathey, Chem. Rev., 1990, 90, 997-1025.

18 R. C. Fischer and P. P. Power, Chem. Rev., 2010, 110, 38773923.

19 P. V. R. Schleyer, C. Maerker, A. Dransfeld, H. Jiao and N. J. R. van Eikema Hommes, J. Am. Chem. Soc., 1996, 118, 6317-6318.

20 B. Breit, U. Bergsträsser, G. Maas and M. Regitz, Angew. Chem., Int. Ed., 1992, 31, 1055-1058.

21 The $[\mathrm{P}]-\mathrm{PCO}$ to $[\mathrm{P}]-\mathrm{OCP}$ energy difference is in good agreement with the recently calculated value, see ref. 11. 
22 S. G. Weber, C. Loos, F. Rominger and B. F. Straub, ARKIVOC, 2012, 2, 226-242.

23 For P- transfer from PCO see for example: (a) A. M. Tondreau, Z. Benkö, J. R. Harmer and H. Grützmacher, Chem. Sci., 2014, 5, 1545-1554; (b) T. P. Robinson, M. J. Cowley, D. Scheschkewitz and J. M. Goicoechea, Angew. Chem., Int. Ed., 2015, 54, 683-686. 24 The ${ }^{13} \mathrm{C}$ NMR signal is broad as a result of the coupling with several different phosphorus nuclei (see ESI $\dagger$ ).

25 For the addition of nucleophiles to the carbon atom of phosphaketenes, see: (a) Z. Li, X. Chen, Z. Benkő, L. Liu, D. A. Ruiz, J. L. Peltier, G. Bertrand, C.-Y. Su and
H. Grützmacher, Angew. Chem., Int. Ed., 2016, 55, 60186022; (b) R. Appel, P. Foelling, B. Josten, W. Schuhn, H. V. Wenzel and F. Knoch, Z. Anorg. Allg. Chem., 1988, 556, 7-22; (c) R. Appel, P. Foelling, W. Schuhn and F. Knoch, Tetrahedron Lett., 1986, 27, 1661-1664; (d) R. Appel, C. Porz and F. Knoch, Chem. Ber., 1986, 119, 2748-2755; (e) R. Appel, P. Foelling, B. Josten, M. Siray, V. Winkhaus and F. Knoch, Angew. Chem., Int. Ed. Engl., 1984, 96, 619-621.

26 X. Chen, S. Alidori, F. F. Puschmann, G. Santiso-Quinones, Z. Benkö, Z. Li, G. Becker, H.-F. Grützmacher and H. Grützmacher, Angew. Chem., Int. Ed., 2014, 53, 1641-1645. 